\title{
Soil water balance simulated by CROPGRO-Drybean model for edaphoclimatic conditions in Maringá
}

\author{
Rivanildo Dallacort ${ }^{1}$, Paulo S. L. de Freitas ${ }^{2}$, Rogério T. de Faria ${ }^{3}$, \\ Antonio C. A. Gonçalves ${ }^{2}$, Aleksandra G. Jácome 4 \& Roberto Rezende ${ }^{2}$
}

\begin{abstract}
The performance of the CROPGRO-D rybeans model for the prediction of soil water balance, as well as growth components and bean crop yield, was assessed using data from two field experiments conducted at the State University of M aringá Irrigation Technical Center, Paraná - Brazil, (latitude 23027'S, longitude 51057' and altitude $542 \mathrm{~m}$ ), during the 2005 and 2006 growing season. The model simulations correlated well with measured soil moisture $(r>0.7)$ for both experiments. However, there were high discrepancies between measured and simulated soil moisture values on the days after rainfall. In addition, it was found that the model exaggerates the effect of water stress during the flowering phase, which leds to underprediction (19 and $29 \%$ ) of crop yield.
\end{abstract}

Key words: water stress, soil moisture, simulation

\section{Balanço da água no solo simulado pelo modelo CRO PGRO - Drybean para as condições edafoclimáticas de Maringá}

\section{RESUMO}

\begin{abstract}
0 desempenho do modelo CRO PGRO -D rybeans para predição do balanço de água no solo, componentes de crescimento e produtividade, foram avaliados por meio de dados de dois experimentos de campo conduzidos no Centro Técnico de Irrigação da Universidade Estadual de Maringá, localizado em Maringá, PR (latitude 23 25' S, longitude de 51 57' 0 , altitude de 542 m), nos os anos agrícolas de 2005 e 2006. Concluiu-se que o modelo simulou estresse hídrico maior que o real na fase de florescimento, subestimando o rendimento em 19 e $29 \%$. Os valores de umidade do solo medidos no campo e simulados pelo CROPG RO, foram bem correlacionados ( $r>0,7$ ), porém houve discrepância acentuada nos valores medidos e simulados no dia posterior à ocorrência da precipitação.
\end{abstract}

Palavras-chave: déficit hídrico, umidade do solo, simulação

\footnotetext{
IDAG UNEM AT, Campus Universitário de Tangará da Serra, 358, km 07, C.P. 287, CEP: 78300-000, Tangará da Serra, MT. Fone: (65) 3329-3320. E-mail: rivanildo@unemat.br

2 DAG/ UEM, Av. Colombo, 5790,CEP 87020-900, Maringá, PR. Fone: (44) 3261-8916. E-mail: pslfreitas@uem.br; acagoncalves@uem.br; rrezende@uem.br 3IAPAR Rodovia Celso Garcia Cid, km 375, CP 481, CEP 86047-902, Londrina, PR. Fone: (43) 3376 2000. E-mail: rtfaria@iapr.br

4 FESAR Rodovia PA 287, km 15 CP 131, CEP: 68550-000, Redenção, PA Fone: (94) 81182006.E-mail: agjacome@bol.com.br
} 


\section{INTRODUCTION}

The complexity of the agricultural decision making process has led researchers to develop decision support systems based on computer models. These systems generate information for the various management options considering the local environmental conditions.

Growth simulation models are valuable tools for estimating crop yield, considering the various combinations of crop input, environmental factors and management practices. In order to estimate crop yield, agrometeorogical based models simulate the crop development, available soil moisture and the effects of water stress on the crop yield. Some models are classified as dynamic and mechanistic because they describe daily changes on the plant state variables, considering the main morphophysiological processes that occur in the period of simulation. Using simulation, the most suitable strategies can be assessed in each specific condition, such as irrigation management strategies, which can be simulated to predict effects on crop yield and hydrologic components, such as evapotranspiration and crop water requirements. Furthermore, the results of the model can be combined with economic factors to analyze the risks associated with each strategy (Jones \& Ritchie, 1990). Whisler et al. (1986) and Jones \& Ritchie (1990) reported a series of crop growth simulation models that can be applied widely, including in irrigation management.

Some simulation models use genetic coefficients as inputs, which permit simulating crop performance in different soils, climate and environmental conditions. Hunt et al. (1993) developed the program Gencalc (genetic coefficient calculator) to facilitate the calculation of the genetic coefficients used in models that are estimated from the field experimental data. The values simulated by the model are compared with the experimental data and the coefficients are adjusted until achieving a close agreement among simulated and field data.

The usefulness of models applied locally can be extended by regional planning and crop yield analysis and using them combined with geographic information systems (Cabelguenne et al., 1995). Cabelguenne \& Jones (1989) and Lal et al. (1993) also used simulation models to define irrigation and management strategies and to study crop economic viability. Scheduling irrigation for maize crop requires knowledge of methods to determine the time of water application. Freitas et al. (2004) and Gedanken (1998) used the Ceres-Maize model to simulate maize crop yield using different irrigation strategies.

In this context, DSSAT (Decision Support System for Agrotechnology Transfer) is a computer system that includes several crop growth models that have been used by many researchers under the most varied climatic and soil conditions, and is an excellent alternative to obtain information that helps in agricultural planning and management (Hoogenboom et al., 1992). The system DSSAT uses a common soil-water balance module in several models for different crops: maize (CeresMaize), soybean (Cropgro-soybean), the common bean (Cropgrodrybean), wheat (Ceres-Wheat), sorghum (Ceres-Sorghum), rice (Ceres-Rice), barley (Ceres-Barley), sunflower (Ceres-Sunflower) etc. (IBSNAT, 1989).

Meirelles et al. (2003) and Faria \& Bowen (2003) pointed inaccuracies of the DSSAT soil-water balance module and suggested changes to improve model prediction. Freitas et al. (2005) observed that CERES-Maize severely penalized yield during periods of water shortage. They also highlighted the need for research to test the soil-water balance model used, requiring research in experimental fields, monitoring the edaphoclimatic conditions and adjustments to the model when necessary and possible. By testing the models, the researchers proved whether the use of certain models in certain regions was reliable.

The objective of this study was to test the soil-water balance module in CROPGRO-Drybean model against field data from experiments conducted with a bean crop under edaphoclimatic conditions of Maringá, Paraná, Brazil.

\section{MATERIAL AND METHODS}

\section{Experimental procedures}

The present study was carried out at the Irrigation Technical Center at the State University of Maringá, located in Maringá, (latitude $23^{\circ} 25^{\prime} \mathrm{S}$, longitude $51^{\circ} 57^{\prime} \mathrm{W}$ and altitude $542 \mathrm{~m}$ ). The predominant climate in the region, according to the Köppen, is classified as Cfa type, characterized by high rainfall in the summer and dry winter, with 1,673 mm annual mean rainfall. The annual mean temperature in the region is $23.2^{\circ} \mathrm{C}$ and the air relative humidity is $68 \%$. The predominant soil in the experimental area is classified as Nitossolo Vermelho distroférrico (EMBRAPA, 1999), with moderate A horizon and clay texture. The relief presented an average slope of $8 \%$.

Two experiments were carried out with a bean crop (Phaseolius vulgaris L.), cultivar IAPAR 81, during the 2005 and 2006 growing seasons, from May 4 to August 15, 2005, and April 12 to July 26, 2006, respectively. The experimental area $\left(720 \mathrm{~m}^{2}\right)$ used was subdivided into 80 experimental units $(3.0$ x $3.0 \mathrm{~m}$ ). After sowing, a fixed conventional sprinkler irrigation system was installed using Fabrimar sprinkler, model A232 ECO, at $18 \times 15 \mathrm{~m}$ spacing, covering experimental plots and the border.

Soil moisture was determined by TDR, using 80 probes 0.30 $\mathrm{m}$ long in the first experiment and 80 probes $0.20 \mathrm{~m}$ length in the second experiment, all installed vertically from the soil surface at the center of each experimental unit. Apparent dieletric constants of the environment $(\mathrm{Ka})$ were measured daily and were then converted into soil moisture $\theta\left(\mathrm{m}^{3} \mathrm{~m}^{-3}\right)$ using the following relationship (Trintinalha, 2005).

$$
\begin{aligned}
& \theta=(0,842538-0,725175 \mathrm{ds})+(-0,049601+0,060353 \mathrm{ds}) \mathrm{Ka}+ \\
& (0,001044-0,001061 \mathrm{ds}) \mathrm{Ka}^{2}
\end{aligned}
$$

Crop yield $\left(\mathrm{kg} \mathrm{ha}^{-1}\right)$ was determined by multiplying plant yield, obtained from ten plant samples collected randomly in each experimental unit, by plant population in each experimental unit. Seeds were manually detached from pods to deter- 
mine the seed mass, after drying in a ventilated stove at 70 ${ }^{\circ} \mathrm{C}$ until constant weight.

\section{Model characteristics}

The CROPGRO-Drybean model (Hoogenboom et al., 1994) was developed to simulate growth, development and yield of a common bean crop. It considers the plant's main physical and physiological processes, such as photosynthesis, respiration, biomass accumulation and partition, phenology, soil water extraction, evapotranspiration and common bean growth and leaf area development as functions of daily climatological elements (rainfall, solar radiation, maximum and minimum temperature), for the specific conditions of soil. Water storage in the soil and its capacity to supply the plant roots are predicted based on the processes of superficial runoff, water percolation and redistribution in the profile. The model is sensitive to the characteristics of each cultivar, sowing dates, crop spacing and irrigation management options.

Cultivar characteristics are expressed in the model by the genetic coefficients in order to express phenological traits related to growth and development of each genotype. The genetic coefficients for cultivar IAPAR 81 were obtained by interactively adjusting the values of the coefficients until flowering and maturity dates matched the experimental values, and simulated dry matter coincided with measured grain yield.

The genetic coefficients calibrate for the IAPAR 81 cultivar are given in Table 1 . These values are slightly different from the coefficients calibrated for IAPAR 57 (Faria et al., 1997) because IAPAR 81 has a higher yield potential (IAPAR, 2006).

Table 1. Calibrated genetic coefficients* for the cultivar IAPAR cultivar 81

\begin{tabular}{cccccccc}
\hline CULTIVAR & CSDL & PPSEN & EM-FL & FL-SH & FL-SD & SD-PM & FL-LF \\
IAPAR 57 & 12.00 & 0.000 & 28.7 & 3.0 & 9.5 & 28.50 & 16.84 \\
LFMAX & SLAVRN & SIZLF & XFRT & WTPSD & SFDUR & SDPDV & PODUR \\
1,00 & 308 & 133.0 & 1.00 & 0.251 & 12.5 & 4.12 & 9.1 \\
\hline
\end{tabular}

${ }^{*}$ CSDL - critical day length, above which the reproductive development process is not affected $(\mathrm{h})$; PPSEN - response inclination regarding development for the photo phase with time $\left(1 \mathrm{~h}^{-1}\right)$; EM-FL - period between plant emergence and the appearance of the first flower (R1) (photothermal days); FL-SH - period between the appearance of the first flower and the first pod (R3) (photothermal days); FL-SD - period between the appearance of the first flower and the start of seed formation (R5) (photothermal days); SD-PM - period between the start of seed formation and physiological maturity (R7) (photothermal days); FL-LF - period between the appearance of the first flower (R1) and the end of leaf expansion; LFMAX - maximum leaf photosynthesis rate at an optimal temperature rate of $30^{\circ} \mathrm{C}$; SLAVARN - specific leaf area under standard growth conditions $\left(\mathrm{cm}^{2}\right)$; SIZLF - maximum size of completely expanded leaf $\left(\mathrm{cm}^{2}\right)$; XFRT - maximum fraction of the daily growth that is partitioned between the seed plots the pod; WTPSD - maximum weight per seed (g); SFDUR - duration of the grain swelling period in the pods, under standard growth conditions (photothermal days); SDPDV - mean seeds per pod, under standard growth conditions (photothermal days); PODUR - time necessary for the cultivar to reach ideal pod conditions (photothermal days)

Besides genetic coefficients of the cultivar IAPAR 81, other inputs for the model were climatological and soil data. The set of daily climatological variables was formed by maximum air temperature, minimum air temperature, rainfall and sunshine hours, which were obtained from INMET meteorological station, located close to the experimental field.

Soil samples were collected from the experimental area to determine the soil inputs (Table 2). Soil water retention and bulk density were determined from undisturbed samples obtained at metallic ring $(5 \mathrm{~cm}$ diameter by $5 \mathrm{~cm}$ height $)$ and particle size distribution was determined by the Bouyoucos method (Gee \& Bauder, 1986) at the Soil Laboratory of the Department of Agriculture, State University of Maringá . The samples were used to determine the soil water retention curve, using the tension table for the potentials between 0 and $-6 \mathrm{kPa}$ and a Richards Chamber (Richards, 1948), for the other processes or potentials. Soil moisture $\theta\left(\mathrm{m}^{3} \cdot \mathrm{m}^{-3}\right)$ was obtained as a function of the pre-established tensions ( $\psi \mathrm{m})$ $\mathrm{kPa}$. The upper moisture limit (field capacity) was considered as the water content retained at $-6 \mathrm{kPa}$ (Reichardt, 1990) and the lower limit (permanent wilting point) at -1500 $\mathrm{kPa}$ (Figure 1).

Table 2. Soil physical characteristics for the $0-30 \mathrm{~cm}$ depth of the soil at the experimental area

\begin{tabular}{ccccccc}
\hline \multicolumn{2}{c}{ Soil water retention } & $\left(\mathrm{m}^{3} \mathrm{~m}^{-3}\right)$ & \multicolumn{3}{c}{ Bulk } & \multicolumn{3}{c}{ Particle size distribution (\%) } \\
Saturation & $\begin{array}{c}\text { Upper } \\
\text { Lower }\end{array}$ & $\begin{array}{c}\text { density } \\
\left(\mathrm{g} \mathrm{cm}^{-3}\right)\end{array}$ & $\begin{array}{c}\text { Sand } \\
\text { Limit }\end{array}$ & $\begin{array}{c}\text { Lilt } \\
\text { Limit }\end{array}$ & Clay \\
0.58 & 0.44 & 0.34 & 1.34 & 12 & 12 & 76 \\
\hline
\end{tabular}

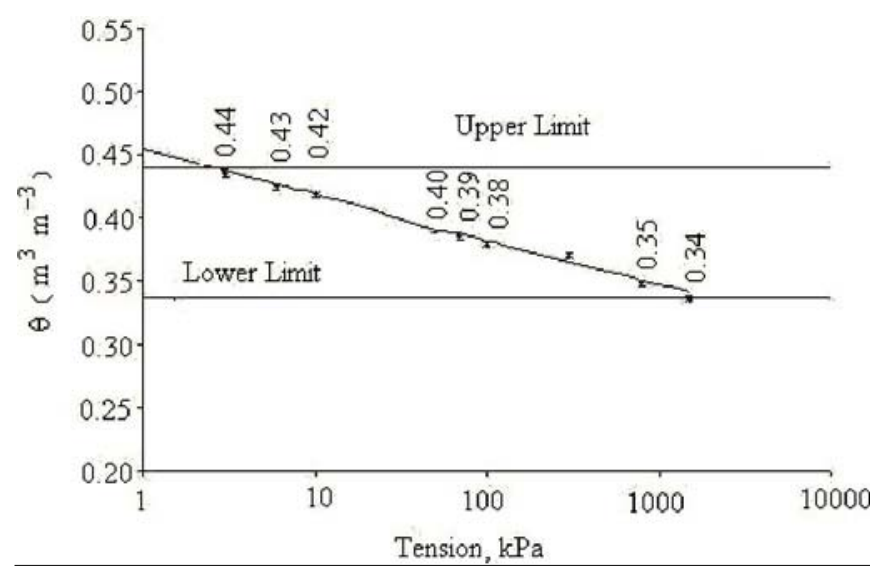

Figure 1. Soil water retention curve

Simulations were performed for the two growth cycles, for same periods the experiments were carried out.

\section{RESULTS AND DISCUSSION}

\section{Rainfall and irrigation}

During the experimental period total rainfall plus irrigation for the 2005 and 2006 growing seasons were 332 and $303 \mathrm{~mm}$ (Figure 2). These values meet the crop water requirements during the growing cycle found by other authors conducting experiments in Brazil (Guimarães, 1996; Faria, 1989; Silveira \& Stone, 2001). Also Doorenbos \& Kassam (2000) concluded 
A.

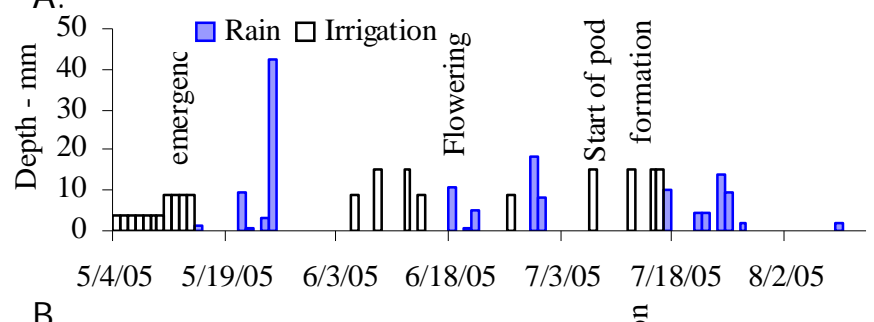
B.

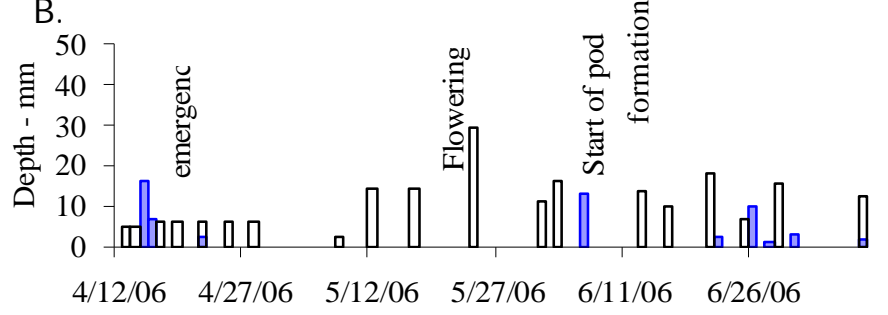

Date

Figure 2. Rainfall and irrigation events during the experiments carried out in 2005 (A) and 2006 (B)

that maximum bean yield is achieved when 300 to $400 \mathrm{~mm}$ is available during the cycle, depending on the local edaphoclimatic conditions.

The water application uniformity coefficient of the sprinkler system was $80 \%$ in the first experiment and $81 \%$ in the second experiment, values considered acceptable in a sprinkler irrigation system (Bernardo et al., 2005). For the 2005 experiment, from emergence to flowering (May 10 to June 15) a total of $147.3 \mathrm{~mm}$ was concentrated, which corresponded to $44.4 \%$ of the total rainfall of the crop cycle. From flowering to start of pod formation (June 16 to July 15) $83.5 \mathrm{~mm}$ well distributed rainfall occurred to fill crop water requirements. According to Guimarães (1996) and Massignam et al. (1998) water shortage at this phase would cause large decreases in yield. Finally, during grain filling, $77 \mathrm{~mm}$ of irrigation plus the well distributed rainfall that occurred during the period were sufficient to supply crop water requirements. For the experiments carried out in 2006, the crop received a total of $112.7 \mathrm{~mm}$ during emergence to flowering, corresponding to $37.2 \%$ of the total rainfall in the crop cycle. From flowering to start of pod formation the crop was supplied with $45.1 \mathrm{~mm}$ water, $34.6 \mathrm{~mm}$ less than for the 2005 experiment. Finally, from pod formation to maturity the crop had $105.4 \mathrm{~mm}$.

\section{Soil moisture predictions}

Simulations of soil moisture at three soil depths, during 2005 and 2006 growing seasons is shown in Figure 3. Higher variation in soil moisture occurred at the top layer $(0-5 \mathrm{~cm})$ because it was most influenced by the climatological factors. During the 2005, the average soil moisture simulated by the model in the top layer was $0.35 \mathrm{~cm}^{3} \mathrm{~cm}^{-3}$, ranging from 0.23 $\mathrm{cm}^{3} \mathrm{~cm}^{-3}$ to $0.43 \mathrm{~cm}^{3} \mathrm{~cm}^{-3}$. In 2006, the model simulated average soil moisture equal to $0.34 \mathrm{~cm}^{3} \mathrm{~cm}^{-3}$, ranging from 0.23 $\mathrm{cm}^{3} \mathrm{~cm}^{-3}$ to $0.43 \mathrm{~cm}^{3} \mathrm{~cm}^{-3}$.

According to Doorenbos \& Kassam (2000), the conditions that occurred in the $0-5 \mathrm{~cm}$ layer were harmful to the plant on the days when the soil moisture was lower than the lower

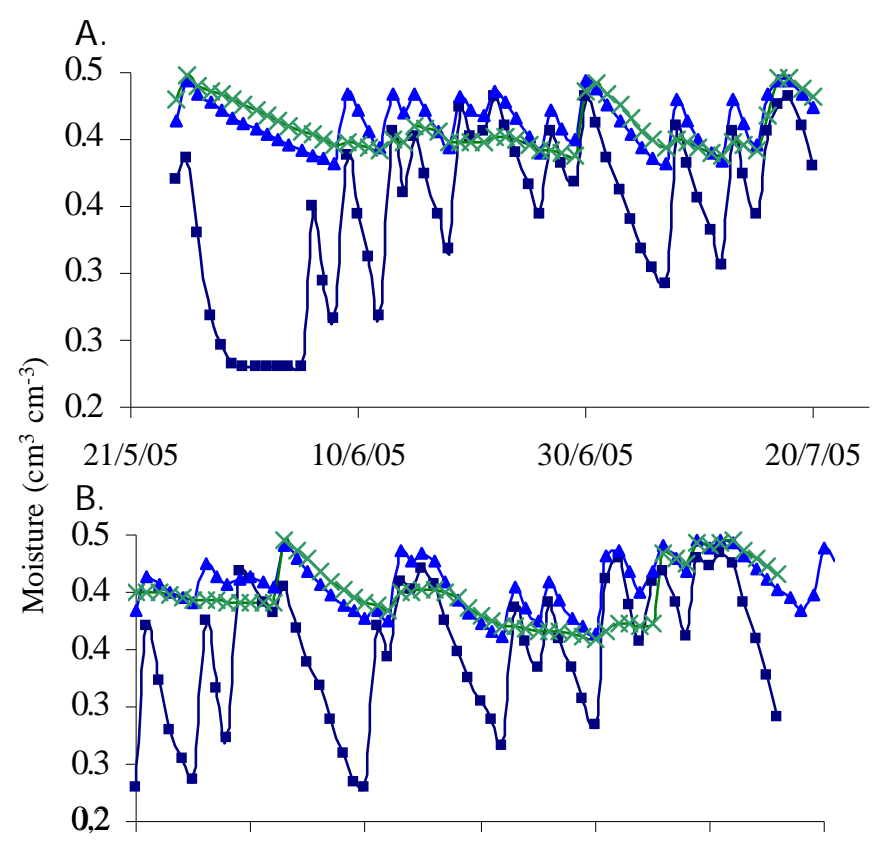

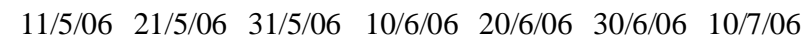

$$
\rightarrow-\mathrm{C} 1 \stackrel{\text { Date }}{\longleftarrow} \mathrm{C} 2 \rightarrow \mathrm{C} 3
$$

Figure 3. Simulated soil moisture during 2005(A) and 2006 (B) growing seasons for three soil depths $\left(c_{1}=0\right.$ to $5 \mathrm{~cm}, c_{2}=5$ to $15 \mathrm{~cm}$ and $c_{3}=15$ to $\left.30 \mathrm{~cm}\right)$

limit, especially right after emergence, when the root system is in the 0-7 cm layer.

The simulated soil moisture for $5-15 \mathrm{~cm}$ and $15-25 \mathrm{~cm}$ layers presented lower variation, with averages of 0.41 $\mathrm{cm}^{3} \mathrm{~cm}^{-3}$ (minimum of $0.38 \mathrm{~cm}^{3} \mathrm{~cm}^{-3}$ and maximum of 0.45 $\mathrm{cm}^{3} \mathrm{~cm}^{-3}$ ) and $0.40 \mathrm{~cm}^{3} \mathrm{~cm}^{-3}$ (minimum of 0.36 and maximum of $0.45 \mathrm{~cm}^{3} \mathrm{~cm}^{-3}$ ), respectively, for the first and second experiment. Inforzato \& Miyasaka (1963) observed 84 and $97 \%$ of bean roots were distributed in $0-20 \mathrm{~cm}$ layer, respectively for two Alfisols.

The comparison of simulated, weighted soil moisture means from 0-5, 5-15 and 15-30 cm layers with the mean soil moisture measured by the TDR is shown in Figure 4. In general, predicted values followed the variation of measured soil moisture during both growing seasons, as reflected by the high correlation coefficient ( $r=0.70$ to 0.74 ). However, the data distribution around the line 1:1 in Figure 4 indicates discrepancies of estimation, mostly for the experiment in 2006. During the first experiment, $64 \%$ of the simulated values were underestimated. The same performance was not observed in the second experiment, when the model overpredicted $74 \%$ of measurements (Figure 5)

Discrepancies in Figure 4 can be attributed to limitations of the model in properly simulating the water absorption by the soil and soil water distribution, as also observed by Faria $\&$ Bowen (2003) when they assessed the performance of the soil-water balance model of the CROPGRO-Drybeans model with soil moisture data measured in bare soil and soil cropped with common bean.

In modeling, validation of the simulated data is extremely important, as suggested by Willmott (1981). Considering that 

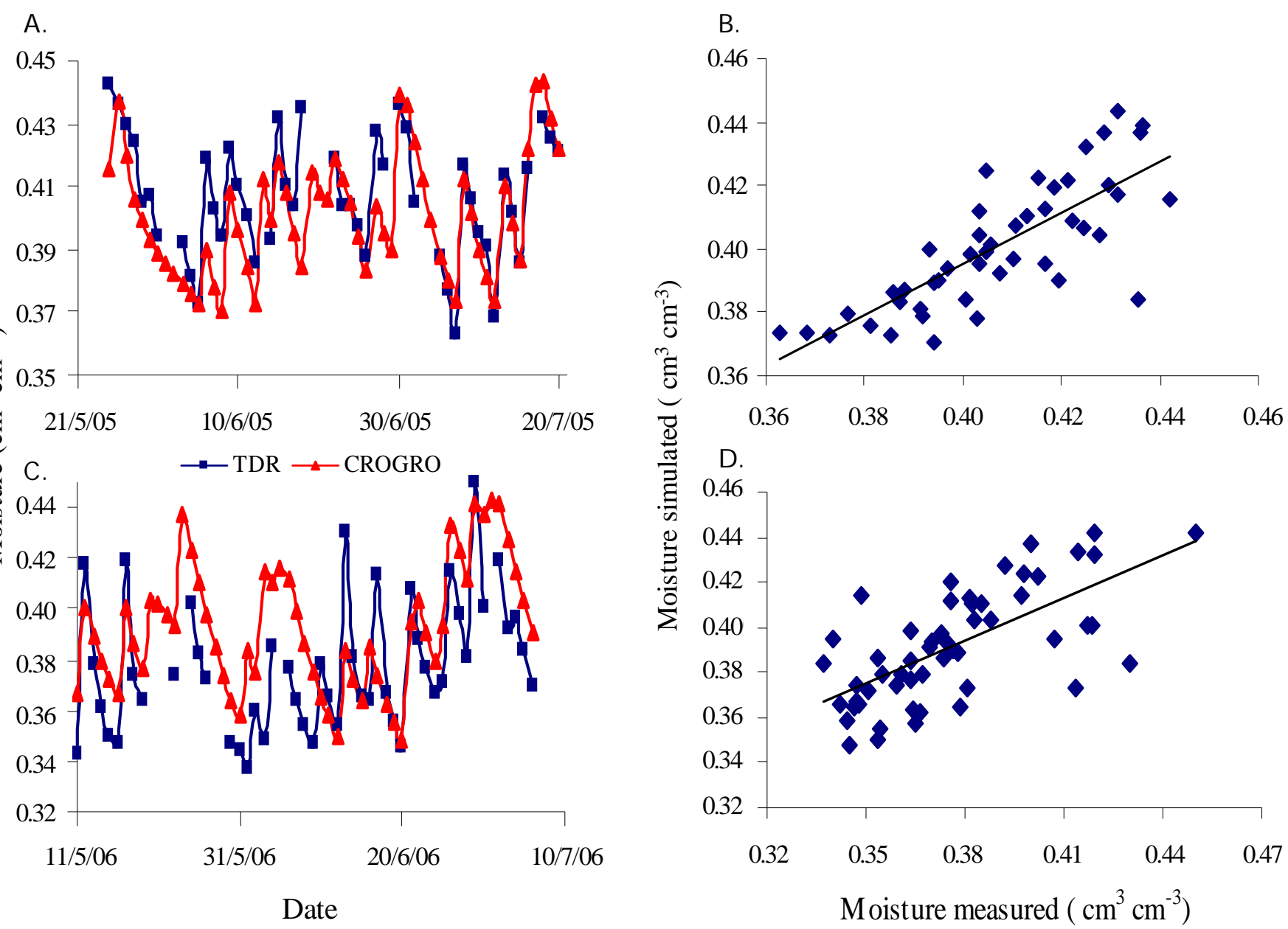

Figure 4. Simulated and measured soil moisture in the $30 \mathrm{~cm}$ layer, during the experiments carried out in 2005 (A and B) and 2006 (C and D)

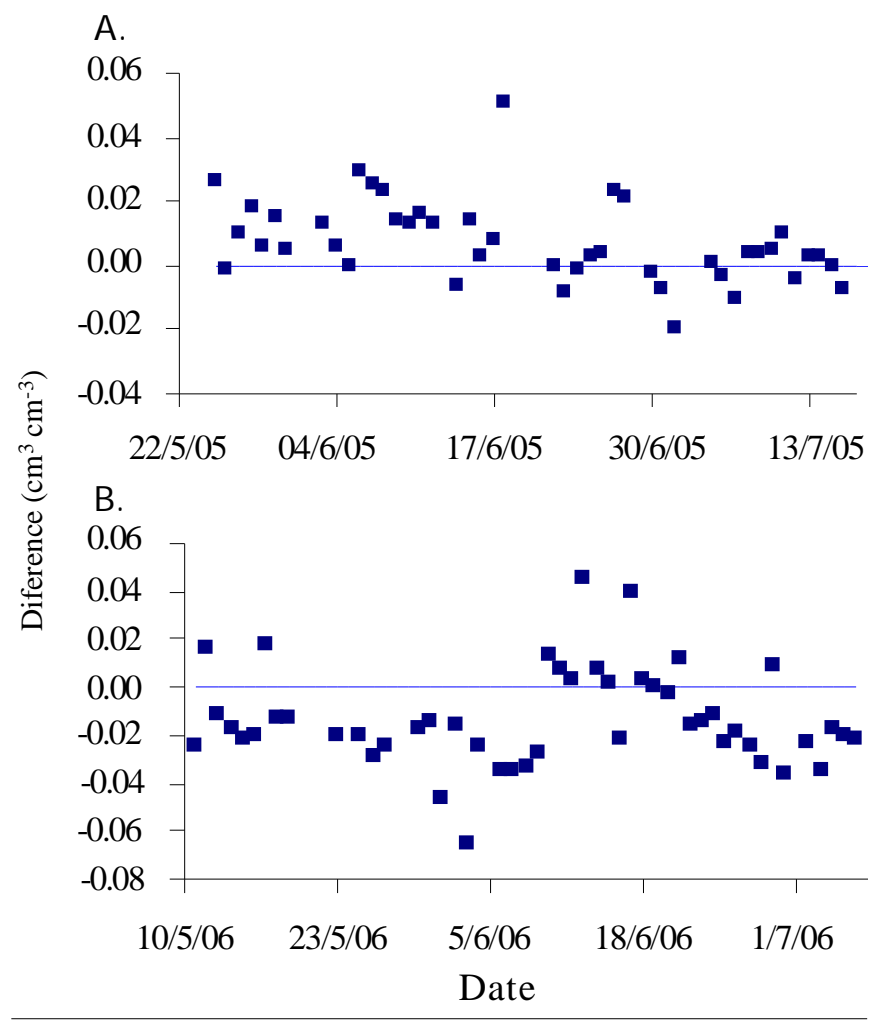

Figure 5. Differences between measured and simulated soil moisture during the experiments 2005 (A) and 2006 (B) numerical models are not exact, but approximate, they were tested by errors of this approximation. It can be observed that mean quadratic error (EQM) ranged from 0.0063 (2005 data) to -0.0152 (2006 data). These values are associated with the model ability to under or overestimate in relation to data mean. On the other hand, the mean quadratic error (REQM) can express data dispersion, assuming values of 0.0142 and 0.0256 for 2005 and 2006 years data, respectively. From these values, we can observe that model slightly overestimated values in 2005 but underestimated in 2006. Also, the REQM values expressed that model estimated values present less dispersion in 2005 than in 2006 year.

\section{Yield}

Measured yield standard deviation and coefficient of variation of bean yield from the 80 experimental units in the 2005 were higher than the values obtained for 2006

Table 3. Simulated yield and measured mean, maximum and minimum yield, standard deviation (SD) and coefficient of variation (CV) determined for the two experiments

\begin{tabular}{ccccccc}
\hline Growing & \multicolumn{7}{c}{ Yield $\left(\mathbf{k g ~ h a}^{-1}\right)$} \\
\cline { 2 - 7 } season & Simulated & Mean & Max & Min & SD & CV (\%) \\
2005 & 2465 & 2830 & 4879 & 1200 & 898.98 & 32 \\
2006 & 1748 & 2462 & 4197 & 1478 & 549.75 & 22 \\
\hline
\end{tabular}


(Table 3). Although predicted values were in the range of mean \pm standard deviation, the model underestimated crop yield by $19 \%$ in 2005 and by $29 \%$ in 2006 (Table 3). This can be attributed to the fact that the model CROPGRO-Drybeans exaggerates the effect of water stress during the flowering phase, which leads to underprediction of crop yield.

\section{CONCLUSIONS}

1. The simulated soil moisture followed measured values, but the model underpredicted soil moisture in 2005 and overpredicted in 2006

2. The model underestimated yield for both experiments (19 to $29 \%$ ) because it overstated the effect of water deficit on crop yield.

\section{LITERATURE CITED}

Bernardo, S.; Soares, A. A.; Mantovani, E. C. Manual de irrigação. 7.ed. Viçosa: UFV, 2005. 611p.

Cabelguenne, M.; Jones, C. A. Simulation of cropping systems in Southern France. In: Summer Computer Simulation Confererence, Austin, 1989, Proceedings... Austin: The Society for Modeling and Simulation International, [S.1.],1989. p.707711.

Cabelguenne, M.; Jones, C. A.; Willians, J. R. Strategies for limited irrigation of maize in southwestern France - a modeling approach. Transaction of the ASAE, v.38, p.507-511, 1995.

Doorenbos, J.; Kassam, A. H. Efeito da água no rendimento das culturas. 2.ed. Campina Grande: UFPB, 2000. 221p. Irrigação e Drenagem, 33.

EMBRAPA - Empresa Brasileira de Pesquisa Agropecuária. Sistema brasileiro de classificação de solos. Rio de Janeiro: Embrapa CNPS, 1999. 412p.

Faria, R. T. Irrigação. O feijão no Paraná. In: Fundação Instituto Agronômico do Paraná, Londrina: IAPAR, 1989. p.145-65. Circular,63

Faria, R. T.; Bowen, W. T. Evaluation of DSSAT soil-water balance module under cropped and bare soil conditions. Brazilian Archives of Biology and Technology, v.46, n.4, p.489-498, 2003.

Faria, R. T.; Oliveira, D.; Folegatti, M. V. Simulação da fenologia e produção do feijoeiro pelo modelo BEANGRO. In: Congresso Brasileiro de Agrometeorologia,10, Piracicaba, 1997. Resumos... Piracicaba: Sociedade Brasileira de Agrometeorologia, 1997. p.141-142.

Freitas, P. S. L.; Mantovani, E. C.; Sediyama, G. S.; Costa, L. C. Simulação da produtividade da cultura do milho em função da lâmina e da uniformidade de aplicação de água. Revista Brasileira de Engenharia Agrícola e Ambiental, v.8, n.2/3, p.225232, 2004.

Freitas, P. S. L.; Mantovani, E. C.; Sediyama, G. C.; Costa, L. C. Penalização da produtividade da cultura do milho imposta pelo modelo CERES-Maize. Acta Scientiarum, v.27, n.1, p.97$105,2005$.
Gedaken, A. Utilização do modelo Cerez-Maize para avaliar estratégias de irrigação em duas regiões de Minas Gerais. 1998. Viçosa: UFV, 1998. 74p. Dissertação Mestrado

Gee, G.W.; Bauer, J.W. Water content. In: Klute, A. (ed.). Methods of soil analysis. Madison: American Society of Agronomy, 1986. p.383-411

Guimarães, C. M. Relações hídricas. In: Araújo, R. S. (Coord.) Cultura do feijoeiro comum no Brasil. Piracicaba: Associação Brasileira para Pesquisa de Potassa e do Fosfato, 1996. p.139167.

Hoogenboom, G.; Jones, J. W; Boote, K. J. Modeling growth, development, and yield of grain legumes using soygro, pnutgro, and beangro: A review. Transactions of the ASAE, v.35, n.6, p.2043-2055, 1992.

Hoogenboom, G.; Jones, J. W.; Wilkens, P. W.; Batchelor, W. D.; Bowen, W. T.; Hunt, L. A.; Pickering, N. B.; Singh, U.; Godwin, D. C.; Baer, B.; Boote, K.J.; Ritchie, J.T.; White, J. W. CROPGRO - DRY Bean. In: Tsuji, G. Y.; Uehara, G.; Balas, S. Crop models: DSSAT v 3. Honolulu: University of Hawaii, 1994. v.2, p.95-281.

Hunt, L. A.; Pararajasingham, S.; Jones, J. W.; Hoogenboom, G.; Imamura, D. T.; Ogoshi, R. M. GENCALC: Software to facilitate the use of crop models for analyzing field experiments. Agronomy Journal, v.85, p.1090-1094, 1993.

IBSNAT- International Benchmark Sites Network for Agrotechnology Transfer - project 1989a. Documetantion for IBSNAT Crop Models Input \& Output Files Version 1.1: for the decision support system for agrotechnology transfer (DSSAT V. 2.1). IBSNAT project. Honolulu: University of Hawaii, 1989. $61 \mathrm{p}$.

IAPAR- Instituto Agronômico do Paraná. Cultivares de feijão: Principais características das cultivares de feijão com sementes disponíveis no mercado. http://www.iapar.br/noticias/ feijao2.html. 03 Out. 2006.

Inforzato, R.; Miyasaka, S. Sistema radicular do feijoeiro em dois tipos de solo do Estado de São Paulo. Bragantia, v.22, n.38, p.477-481, 1963.

Jones, J. W.; Ritchie, J. T. Crop growth models. In: Hoffman, G. J.; Howel, T.A.; Solomon, K. H. Management of farm irrigation systems. St. Joseph: ASAE, 1990. p.63-89.

Lal, H.; Hoogenboom, L. H.; Calixte, J. P.; Jones, J. W.; Beinroth, F. H. Using crop simulation models and GIS for regional productivity analysis. Transactions of the ASAE, v.36, p.175184, 1993.

Massignam, A. M.; Vieira, H. J.; Hemp, S.; Dittrich, R. C.; Flesch, R .D.; Victoria, F. B. Ecofísiologia do feijoeiro. I Determinação do período mais crítico à deficiência hídrica do solo. Revista Brasileira de Agrometeorologia, v.6, n.1, p.3539, 1998.

Meirelles, E L.; Pereira, A. P.; Sentelhas, P. C.; Stone, L. F.; Zimmermann, F. G. P. Risco climático de quebra de produtividade da cultura do feijoeiro em Santo Antônio de Goiás, GO. Bragantia, v.62, n.1, p.163-171, 2003.

Reichardt, K. A água em sistemas agrícolas. São Paulo: Manole, 1990. 188p.

Richards, L. A. Porous plate apparatus for measuring moisture retention and transmission by soil. Soil Science, v.66, p.105110, 1948. 
Silveira, P. M. S.; Stone, L. F. Irrigação do feijoeiro. Santo António de Goiás: Embrapa Arroz e Feijão, 2001. 230p.

Trintinalha, M. A. Utilização da TDR para avaliação da distribuição espacial e estabilidade temporal do armazenamento de água em um Nitossolo Vermelho distroférrico. Maringá: UEM, 2005. 110p. Tese Doutorado
Whisler, F. D.; Acock, B.; Baker, D.; Fye, . N. R. E; Hodges, F. H.; Lambert, J. R.; Lemmon, H. E.; Mckinion; J. M. V;. Reddy, R.. Crop simulation models in agronomic systems. Advances in Agronomy, v.40, p.141-208, 1986.

Willmott, C. J. On the validation of models. Physical Geography, v.2, n.2, p. 184-94, 1981. 